\title{
Analysis of the Trait Sportive Self-Confidence in Team Sports According to Demographic Variances
}

\author{
Mustafa Yaşar Şahin ${ }^{1}$, Alpay Bülbül ${ }^{2}$, Ercan Karaoğlu ${ }^{2}$ \\ ${ }^{1}$ Assoc. Prof. Dr. Gazi University Faculty of Sport Sciences, Turkey \\ ${ }^{2} \mathrm{PhD}$ student in Sport Sciences, Gazi University Health Science Institute, Department of Physical Education and Sports, \\ Turkey \\ Correspondence: Alpay Bülbül, Gazi University Health Science Institute, Department of Physical Education and Sports, \\ Turkey.
}

Received: February 17, 2019

doi:10.11114/jets.v7i4.4068

\author{
Accepted: March 20, 2019 Online Published: March 21, 2019 \\ URL: https://doi.org/10.11114/jets.v7i4.4068
}

\begin{abstract}
This research was conducted to determine the level of athletes' trait sportive confidence and to compare them in terms of demographic variances. In the research which is in the model descriptive survey, Trait Sportive Self Confidence Scale developed by Vealey (1986) was used as data collection tool. Based on typical sampling method of purposive sampling methods, this research sample is consisted of 279 athletes playing in Ptofessional Football League and female-male Volleyball League in Turkey in 2017-2018 season. In the evaluation of the research data, the assumptions of the tests were examined primarily; for unrelated measurements, t-test, one-way analysis of variance (One Way ANOVA) and Kruskal Wallis test. As a result of the research it was determinated that the trait sportive self-confidences of the athlethes were at a high level. When the findings of the study were evaluated in terms of demographic variables, it was determined that there was a significant difference according to the age or the status of the league played.
\end{abstract}

Keywords: trait sport confidence, athlete, team sports

\section{Introduction}

Identifying success, achieving success and identifying the facts affect success in performance-related research in the field of sports and they have always been a subject of interest. According to Vealey et al. (1998), one of the important concepts which is thought to be effective in sports is the performance of the athlete. In this regard, scientists have attached the importance to analyze the concepts that determinate or affect the performance of sports for many yeears. It is seen that one of the psychological factors that determine and affect performance in sports is the concept of self-confidence in sport (Micoogullari \& Kirazci, 2010).

Self confidence, one of the key elements of psychological life, is an emotional necessity. When most of the basic requirements of a person who doesn't find oneself precious to a certain degree, that person lives in difficulty (McKay \& Fanning, 2005). Self-confidence is an important concept that affects the performance of the sport in the axis of thought and behavior (Jones \& Hanton, 2001). The concept of self-confidence in sport and exercise research has been conceptualized by expressing sport confidence, self-efficacy, performance expectancy and perceived competence (Corbin, et all 1983; Griffin \& Keogh, 1982; Çetinkaya, 2018).

Vealey (1986) used sport confidence to express his belief in the successful performance of an athlete and the degree of its certainty. He also defined sportive self-confidence as the beliefs or values that an individual has about his abilities to succeed in sport. Sporty self-confidence is explained in two ways. The first one is the self-confidence in sport which is special to a certain circumstance, certainnes of the performance or behavioral responses. The other is consisted of the concept of trust that takes places consistently (Cox, 1998). In addition, Vealey (2001) expressed the conceptualized model of sportive confidence as talent and demonstration, physical and mental preparation, personal presentation, social support, leadership of the trainer, enviromental comfort, demonstration of situational appropriateness and the experience gained.

Sportive self-confidence can be shaped by the general sociocultural forces as well as by sport-specific organizational culture surrounding the sport and exercise environment. It's stated that the sportive confidence can be a 
multi-dimensional structure which has many aspects such as other personality traits. Accordingly, sportive self-confidence has dimensions of learning and practicing physical skills, having the ability of using psychological skills, using perceptual skills and being satisfied with the level of physical fitness (Weinberg \& Gould, 2003).

While Trait Sportive self-confidence is generally defined as the individual's perceptions about his/her ability to succeed in sport, situational sportive self-confidence is defined as the individual's current perceptions of his/her ability to succeed in sport in a certain period of time (Bozkurt et al., 2012).

According to the researches which conceptualizes the situational sportive self-confidence, confidence in sportive performances can be measured instantaneously. In this respect, it is a better behavior determinant when compared to the trait sportive confidence. In other words, it expresses the individual's belief in being successful in a certain period of time. However, this situation is not prioritized when it comes to trait sportive confidence. Sportive confidence can give us an idea about which individuals can exhibit which patterns of behavior for which different situations of sport. Therefore, trait sportive confidence remains a bit more backwards when compared to the situational sportive confidence (Vealey et al., 1998).

When the different studies of the subject are examined, Lirgg (1991) lists sportive self-confidence among the factors affecting the performance in sport. In their researches Feltz et. al. (2008) state that self-confidence is one of the topics discussed in the field of sport psychology and refer to it as a dominant psychological process supposed to affect the performance in sport.

In this conceptual framework, the aim of this study is to examine the sportive self-confidence levels of athletes engaged in team sports in terms of various demographic variances.

\section{Method}

This section contains information about the model, universe, and sample of the research, data collection tools and data analysis. The aim of this study is to determine the level of trait sportive self-confidence in football and volleyball team players and to study the level of trait sportive self-confidence in athletes according to demographic characteristics.

In this respect, the study is an example of the survey model from quantitative research methods. Demographic characteristics of athletes within the scope of research were considered as independent variables; while perpetual sportive self-confidence levels were considered as dependent variables.

\section{Working Group}

Within the scope of research, a total of 279 athletes playing in the Turkish professional football league and the Turkish women's and men's volleyball leagues were approached. The research was based on typical sampling method which is some sort of purposive sampling method. Distribution of athletes according to demographic characteristics has been examined.

\section{Data Collection Tools}

Within the scope of this study, data were collected with personal information form and perpetual SportiveSelf-Confidence Scale. General information about data collection tools is given in headings.

\section{Personal Information Form}

With intent to gather data about genders, ages, duration of being a sportsman, the current league of a team, previous status of being in a national team, personal data form was prepared by the researchers. For each variance, based on research's purpose, categories for choosing were created in personal information form.

\section{The Schale of Trait Sportive Self-Confidence}

In order to determine the level of sportive self-confidence of the athletes, sportive confidence format of 13-point Sportive Confidence Scale developed by Vealey (1986) was used. The adaption of the subscale which is consisted of one dimension and graded as quinary Likert-Type scale to Turkish was made by Yıldırım (2013). In the adaption to Turkish process, sportive self-confidence subscale was applied to a total of 160 people, 80 of whom played sports and 80 of whom didn't play sports. In the direction of the participants' answers, exploratory factor analysis was calculated and it was determined that the items in the scale were gathered in one dimension. It was determinated that the factor-load value varied between 0,62 and 0,73 and it clarified D,48 of the total variance. The Cronbach's alpha reliability coefficient of the scale was calculated as 0.89 and test-retest reliability coefficient was calculated as 0.78 (Yıldırım, 2013).

In this research, The Scale of Sportive Trait Self-Confidence was applied to 279 athlethes playing in team sports. In this direction, validity and reliability studies were carried out in line with the answers given by the athletes to the scale items. Primarily, exploratory factor analysis was performed and following research was determined that there was a factor 
which has an eigen value greater than 1 (eigen value:8.400). It was determined that the factor-load values of 13 items in the scale was varied between 0,757 and 0,835 and it clarified \%64,612 of the total variance. Cronbach's alpha reliability of the answers given by the athlethes to the 13 items in the scale was calculated as 0,954 . Confirmatory factor analysis was also calculated in line with the answers given by the athletes to the scale items. As a result of the calculation, it was determined that all items had a meaning full explanatoriness ( $t$ values were significant) in the dimensions they belong to. It was found that the standardized factor-load values $(\lambda)$ of items ranged from 0.78 to 0.85 ; regression coefficients varied between 0.61 and 0.73 . Model-data compliance values indicate that the scale shows a one-dimensional structure in line with the answers given by the adult team sport players to the items in the scale. $\left(X^{2} / s d=3,95\right.$; RMSEA $=0,078$; $\mathrm{SRMR}=0,041 ; \mathrm{CFI}=0,97 ; \mathrm{NFI}=0,96 ; \mathrm{NNFI}=0,96)$. The path diagram created after confirmatory factor analysis is shown below.

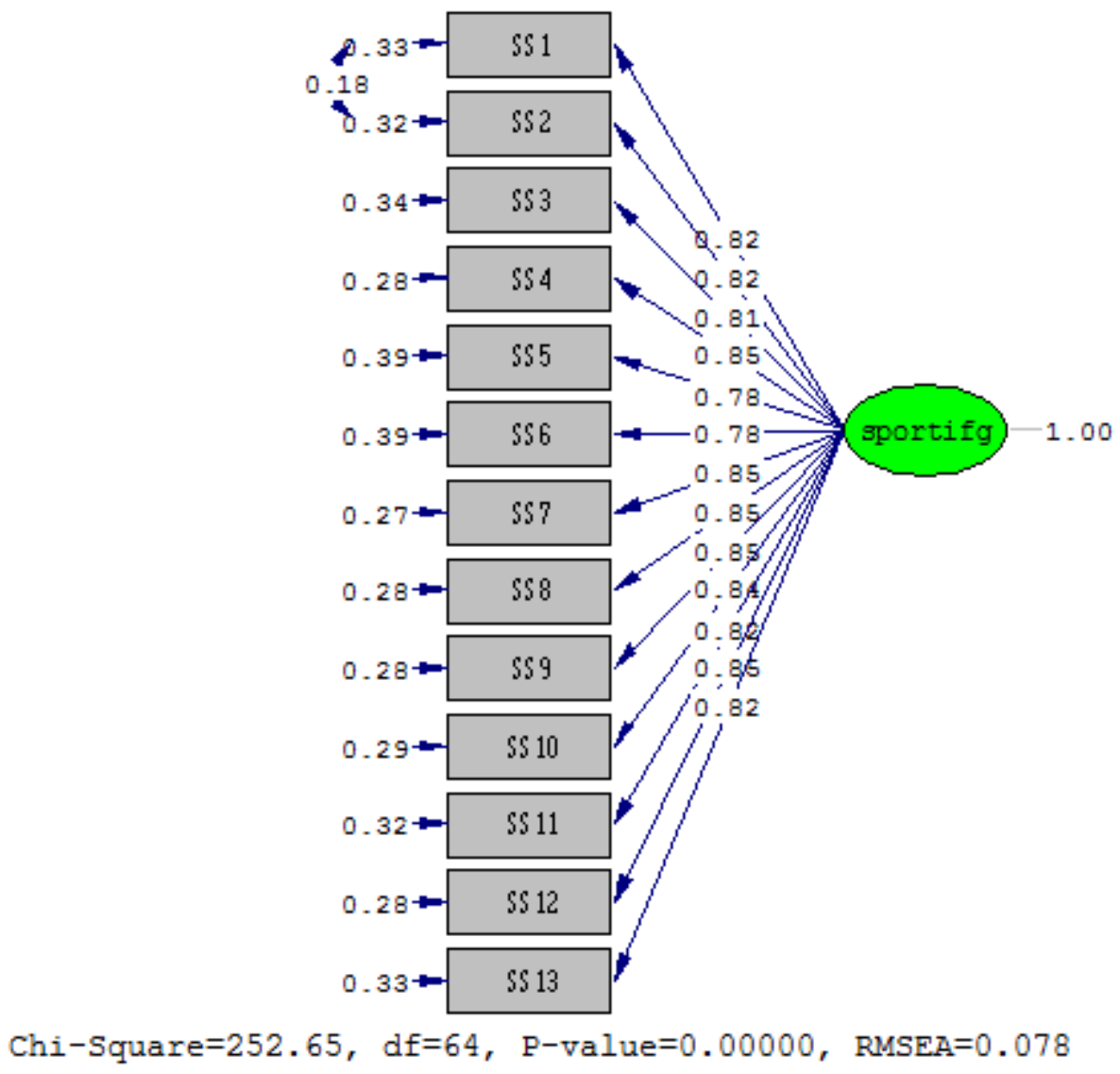

Figure 1. Diagram of Sportive Trait Self-Confidence Sub-Scale

\section{Analysis of Data}

Primarliy, descriptive statistics of the data collected in the research (number of people, minimum, maximum, average, standard deviation) were calculated. Then, the data were analyzed in accordance with the problems of the research.

First of all, skewness and kurtosis coefficients were calculated for the purpose of examining the distribution of scores of the athletes about sportive trait self-confidence levels; skewness coefficient was calculated as $-0,366(0,146)$ and the coefficient of creep was calculated as $-0.460(0.291)$. Büyüköztürk (2004) states that the data shows a normal distribution if the skewness and kurtosis coefficient is between \pm 1 . In this respect, it was determined that the sportive self-confidence scores of the athletes participating in the study showed normal distribution. In addition, a histogram graph was created to determine the distribution pattern and shown in the Figure 2. 


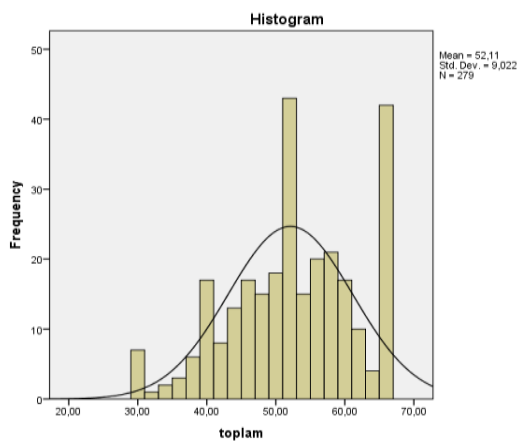

Figure 2. Histogram graph of SportiveTrait Self Confidence Scale

As can be seen in the Figure 2, athletes' sportive self-confidence scores show normal distribution.

It has been examined whether sportive trait self-confidence levels of athletes show a significant difference according to their branches, genders, ages, duration of being athlete, their participation in the league and national team camp. In this direction, the assumptions of the tests were examined first; for unrelated measurements, t-test, one-way analysis of variance (One Way ANOVA) and Kruskal Wallis test. In the difference tests, P value was considered as 0.05 .

\section{Findings}

\section{Descriptive Statistics}

Table 1. Descriptive statistics of team athletes with respect to their sportive self-confidence levels

\begin{tabular}{llllllll}
\hline Scale & $\begin{array}{l}\text { Number } \\
\text { of Items }\end{array}$ & $\mathbf{N}$ & Min. & Max. & $\overline{\mathbf{X}}$ & SS & $\begin{array}{l}\text { Average of } \\
\text { Items }\end{array}$ \\
\hline Sportive Trait Self-Confidence & 13 & 279 & 30,00 & 65,00 & 52,11 & 9,02 & 4,00 \\
\hline
\end{tabular}

When the Table 1 is examined, it was determined that the sportive self-confidence scores of the team athletes who participated in the study ranged from 30,00 to 65,00 , and the average was $52,11( \pm 9,02)$. The mean score obtained from the scale of the athletes was calculated by rating it to the number of items were calculated in the average of 1-5 range and determined as 4.00. Tekin (2002) based on the "range/category" equality (from 1 to 5 points in the scale);

- The scores between 1-2,3 obtained from the scale were low;

- The scores between 2,3-3,7 obtained from the scale were moderate;

- The scores between 3,7-5,00 obtained from the scale were high

In line with this information, it is seen that sportive trait self-confidence of the team athletes is high.

\section{Difference Statistics}

It has been examined whether sportive trait self-confidence levels of athletes show a significant difference according to their branches, genders, ages, duration of being athletes, their participation in the league and national team camp.

Table 2. T-test results of unrelated measurements of team athletes calculated for sportive trait self-confidence levels according to their branches

\begin{tabular}{llllllll}
\hline Scale & Branch & N & $\overline{\mathbf{X}}$ & SS & sd & t & p \\
\hline Sportive Trait Self-Confidence & Football & 172 & 52,81 & 9,09 & & & \\
& Volleyball & 107 & 50,99 & 8,84 & & & 0,102 \\
& & & & & & & \\
\end{tabular}

As can be seen from Table 2 that sportive trait self-confidence levels do not show a significant difference according to the branches. $\left(\mathrm{t}_{(277)}=1,641 ; \mathrm{p}>0,05\right)$. In other words, athletes who play in football and volleyball branches have a similar level of self-confidence. 
Table 3. T-test results of unrelated measurements calculated by the athletes for their sportivetrait self-confidence levels according to their gender

\begin{tabular}{|c|c|c|c|c|c|c|c|}
\hline Scale & Gender & $\mathbf{N}$ & $\overline{\mathbf{X}}$ & SS & sd & $\mathbf{t}$ & p \\
\hline \multirow[t]{2}{*}{ Sportive Trait Self-Confidence } & Male & 204 & 51,70 & 9,91 & \multirow{2}{*}{277} & \multirow{2}{*}{1,148} & \multirow{2}{*}{0,252} \\
\hline & Female & 75 & 53,05 & 6,51 & & & \\
\hline \multicolumn{8}{|c|}{$\begin{array}{l}\text { When the Table } 3 \text { is examined, it is clear that the sportive self-confidence levels of the team athletes did not show a } \\
\text { significant change according to their gender. }\left(\mathrm{t}_{(277)}=1,148 ; \mathrm{p}>0,05\right) \text {. In other words, male and female athletes' sportive } \\
\text { self-confidence levels have similarities. }\end{array}$} \\
\hline \multicolumn{8}{|c|}{$\begin{array}{l}\text { One-way variance analysis was calculated in order to determine whether sportive trait self-confidence of the team } \\
\text { athletes participating in the study showed a significant change according to their age. Before the calculation, the } \\
\text { variance of the scores of the athletes was determined to be homogeneous (Levene }=0,138 ; p>0,05 \text { ). The calculation } \\
\text { results are shown in the Table } 3 \text {. }\end{array}$} \\
\hline \multicolumn{8}{|c|}{$\begin{array}{l}\text { Table } 4 \text {. Results of one-way variance analysis calculated for the level of sportive self-confidence of the team athletes } \\
\text { according to their age }\end{array}$} \\
\hline Scale & Age & $\mathbf{N}$ & $\overline{\mathbf{X}}$ & SS & sd & $\mathbf{F}$ & $\mathbf{p}$ \\
\hline \multirow[t]{3}{*}{ Sportive Trait Self-Confidence } & $18-23$ & 117 & 50,70 & 8,81 & \multirow{3}{*}{$\begin{array}{l}2 \\
(278)\end{array}$} & \multirow{3}{*}{3,390} & \multirow{3}{*}{$0,035^{*}$} \\
\hline & $24-28$ & 111 & 52,50 & 9,23 & & & \\
\hline & $29+$ & 51 & 54,51 & 8,61 & & & \\
\hline
\end{tabular}

*p $<0,05$

In the direction of the information in Table 4, it was determined that sportive trait self-confidence levels of the team athletes showed a significant change according to their age. $\left(F_{(2,278)}=3,390 ; p<0,05\right)$. In order to determine the difference, Tukey was used for multiple comparison tests. As a result of the calculation, it was determined that the athletes who are at the age of 29 and over were more self-confident $(54,51 \pm 8,61)$ than the ones who were 18-23 years old $(50,70 \pm$ $8,81)$.

Since the variances related to the level of sportive self-confidence according to the duration of the athletics of the team players whose opinions were taken within the research were homogenious (Levene $=1,778 ; p>0,05$ ), one-way variance analysis was calculated and the results are shown in the Table 4.

Table 5. Results of one-way variance analysis were calculated for the level of sportivetrait self-confidence of team athletes

\begin{tabular}{llllllll}
\hline Scale & $\begin{array}{l}\text { Duration of } \\
\text { the Athletics }\end{array}$ & $\mathbf{N}$ & $\overline{\mathbf{X}}$ & SS & sd & F & p \\
\hline Sportive Trait Self-Confidence & $0-6$ years & 77 & 51,03 & 9,85 & 2 & 0,900 & 0,408 \\
& $7-11$ years & 117 & 52,25 & 8,30 & $(278)$ & & \\
& $12+$ & 85 & 52,91 & 9,20 & & & \\
\hline
\end{tabular}

Table 5 demonstrates that the level of sportive self-confidence of the team athletes does not show a significant change according to their duration of being athletes. $\left(\mathrm{F}_{(2,278)}=0,900 ; \mathrm{p}>0,05\right)$. In other words, it is determined that the sportive trait self-confidence of people who are between 0-6 years, 7-11 years, 12 years and above have similarities. It was determined that the variances of the level of the sportive trait self-confidence of the team players are not homogeneous according to the league they belong to. (Levene $=8,436 ; p<0,05$ ). Accordingly, Kruskal Wallis test was calculated for comparison and the results are shown in Table 5. 
Table 6. The results of the Kruskal Wallis test, which was calculated for the level of sportivetrait self-confidence according to the league their teams belong to.

\begin{tabular}{|c|c|c|c|c|c|c|c|c|c|}
\hline Scale & & League & $\mathbf{N}$ & $\overline{\mathbf{X}}$ & SS & Place $\bar{X}$ & sd & $\mathbf{X}^{2}$ & $\mathbf{p}$ \\
\hline \multirow{3}{*}{$\begin{array}{l}\text { Sportive } \\
\text { Self-Confidence }\end{array}$} & Trait & Super League & 113 & 51,40 & 8,89 & 134,40 & \multirow{3}{*}{2} & \multirow{3}{*}{12,118} & \multirow{3}{*}{$0,002 *$} \\
\hline & & Premier League & 84 & 54,50 & 10,59 & 164,46 & & & \\
\hline & & Minor League & 82 & 50,65 & 6,80 & 122,66 & & & \\
\hline
\end{tabular}

$* \mathrm{p}<0,05$

As can be seen in the Table 6, the sportive trait self-confidence levels of the team athletes show a significant difference according to the league their teams belong to. $\left(\mathrm{X}_{(2)}^{2}=12,118 ; \mathrm{p}<0,05\right)$. In order to determine the difference, Tamhanedes test was calculated and it was found that the self-confidence of the athletes who played in the first league $(54,50 \pm 10,59)$ was significantly higher than those who played in the second league $(50,65 \pm 6,80)$.

Table 7. T-test results of unrelated measurements calculated for the level of self-confidence of team players according to their participation in the national team camp.

\begin{tabular}{llllllll}
\hline Scale & $\begin{array}{l}\text { Participation in } \\
\text { the Camp }\end{array}$ & $\mathbf{N}$ & $\overline{\mathbf{X}}$ & SS & sd & t & p \\
\hline Sportive Trait Self-Confidence & Yes & 116 & 53,24 & 9,25 & 277 & 1,772 & 0,077 \\
& No & 163 & 51,31 & 8,79 & & & \\
\hline
\end{tabular}

When the Table 7 is examined, it is seen that sportive trait self-confidence levels do not show a significant difference according to the participation of athletes in national team $\operatorname{camp}\left(\mathrm{t}_{(277)}=1,772 ; \mathrm{p}>0,05\right)$. In other words, it was determined that sportive self-confidence of the athletes who participated and did not participate in the national team camp have similarities.

\section{Discussion and Conclusion}

In this part of the research, the findings of the levels of sportive trait self-confidence of the athletes was included and it was determined whether these parameters differ according to the branch, gender, age, time of sports, the type of league and whether or not to participate in the national team camp.

In the analyzes, it was determined that the sportive trait self-confidence of the team athletes was high. Sport psychologists define the self-confidence as the individual's belief in success in order to show the desired performance. Athletes with low self-confidence have doubts about whether they will succeed or not (Weinberg \& Gould, 1999). From this point of view, we can say that the athletes who are playing in the upper leagues and participated in this study might have played a role in high average of sportive self-confidence.

When the participants' trait self-confidence situations according to the branch variance were examined, no significant difference between the groups was seen. The athletes engaged in volleyball and football branches do not change their sporting self-confidence levels. Fahiminezhad, et. al. (2014) found similar results to our findings and did not find any significant relationship between the branches. In this findings of the research conducted by Kara (2014) which reveals the relationship between sportive confidence and the sport branches, it was determined that there were significant differences between the branches. Accordingly, sportive confidence scorse of the athletes doing judo were higher than other branches. It was seen that judo was followed by football, wrestling, bodybuilding and basketball.

When the self-confidence situations of the participants according to the gender variance were examined, no significant difference between the groups was seen. When the related literature is examined, different findings are found in many studies in terms of sportsman identity and gender variables. When the related literature is examined, different findings are found. Studies have shown that male athletes have higher self-confidence than female athletes (Martens, et al, 1982; Ryan \& Pryor, 1976; Vealey, 1988). In addition, Vurgun (2010) found that in both sexes, males and females, sports confidence increased with age. Jones et. al. (1990) found that male athletes' level of sportive self-confidence were higher than female athletes. Lirgg (1991) found differences in favor of males in terms of gender in the axis of sports confidence depending on the conditions of physical activity performed in his study. These results differ from the results of the study.

When the self-confidence situations of the participants according to the age variance were examined, a significant 
difference between the groups was found. In the analysis, trait sportive self-confidence scores of the group at the age of 29 were significiantly higher than the ones at the age of 18-23.

When the related literature is examined, it is stated that age is a factor in cases involving trust. For example, in social confidence, there is a narrowing and enlargement of confidence according to age (Cook et al. 2005). Yamak et al. (2017) describes the high level of sportive confidence according to age as; "The feeling of confidence which develops depending on playing sports for many years may have an affect on this difference. The fact that the athlete knows his/her own limitations based on his/her ability which is also based on many years."

Looking at the related literature, the results of the study support the findings of this study. For example. Cetinkava (2015) has found that trait increases with self-confidence scores with the increase of the age levels. Similarly, in the study of Vurgun (2010), it was determined that sport confidence increased with age. However, Karagün (2014) did not find any relation to age variance in his sportive confidence study.

When the level of sportive confidence was examined according to the duration of sports, it was determined that there was no significant difference between the groups. Çetinkaya and Yetim (2015) in their study found that there was no significant difference between the level of sportive trait self-confidence and the duration of being athlete of the participants. Our findings show parallelism with these results. In his study, Karagün (2014), starting from the date of starting to sport, starting from the beginning of the year, categorized the working group into 16 years and above and he reached the highest scores at the range of 10-12 years. In terms of professional sport life, the highest score range was determined as 16 years or more.

According to the league the participants playing in, it was seen that there were significant differences in the level of sportive self-confidence. In order to determine the source of the differences between the groups, it was found that the players who played in the first league were significantly higher than those who played in the second league. This finding can give us the idea that sportive confidence opportunities can be used more effectively in high level of professionalization in sports.

It was determined that the participants of the national team camps had higher levels of sportive self-confidence but it did not make any significant difference. This finding may indicate that the factor of being a national team player can provide a gain in terms of trait sportive confidence. In their studies Çetinkaya and Yetim (2015) also found that playing in the national team did not have an affect on the level of sportive trait confidence.

\section{References}

Bozkurt, O., Koruç, Z., Arslan, N., \& Kocaekşi, S. (2012). A Comparison of Football Players' Sport Confidence and Self-Efficacy Beliefs According to Their League Level in Turkey. Journal of Physical Education \& Sports Science/Beden Egitimi ve Spor Bilimleri Dergisi, 6(3), 349-356.

Büyüköztürk, Ş. (2004). Veri analizi el kitabı. Ankara: Pegem A Yayıncılık.

Çetinkaya, T. (2015). The Relationships Among Athletic Identity and Trait Sport Confidence in Team Sports. PhD Thesis, Gazi University Health Science Institute, Ankara.

Çetinkaya, T. (2018). Analysis of the Relationship between Body Perception Levels and Social Appearance Anxieties in the Students of School of Physical Education and Sports. Journal of Education and Training Studies, 6(5), 194-200. https://doi.org/10.11114/jets.v6i5.3115

Cetinkaya, T., \& Yetim, A. (2015). Different Variables Investigation of Athletic Identity in Team Sport. PEOPLE: International Journal of Social Sciences, 1(1).

Cook, K. S., Hardin, R., \& Margaret, L. (2005). Coorperation Without Trust? New York: Russel Sage Foundation.

Corbin, C. B., Landers, D. M., Feltz, D. L., \& Senior, K. (1983). Sex Differences in Performance Estimates: Female Lack of Confidence vs. Male Boastfulness. Research Quarterly for Exercise and Sport, 54, 407-410. https://doi.org/10.1080/02701367.1983.10605326

Cox. R. C. (1998). Sport Psychology Conceptes and Applications. Boston, MA: WCB McGraw Hill.

Fahiminezhad, A., Khani, S., \& Ghasemi, A. (2014). The Comparison of Sport Confidence (trait, state, and sports) between Young Athletes in Individual and Team Sports in Shahrood City. European Journal of Experimental Biology, 4(3), 458-462.

Feltz, D. L., Short, S. E., \& Sullivan, P. J. (2008). Self-efficacy in sport. Human Kinetics.

Griffin, N. S., \& Keogh, J. F. (1982). A Model for Movement Confidence. In J.A.S. Kelso \&J. Clark (Eds.), The

Development of Movement Control, New York: Wiley. 
Jones, G. L., Swain, A. B. J., \& Cale, A. (1990). Ancetedents of Multidimensional Competitive State Anxiety and Self Confidence in Elit Inter Collegiate Middle-Distance Runners. The Sport Psychologist, 4(2), 107-118. https://doi.org/10.1123/tsp.4.2.107

Jones, G., \& Hanton, S. (2001). Pre - Competitive Feeling States and Directional Anxiety Interpretations. Journal of Sports Sciences, 19(6), 385-395. https://doi.org/10.1080/026404101300149348

Karagün, E. (2014). Self-confidence Level in Professional Athletes; An Examination of Exposure to Violence, Branch and Socio-Demographic Aspects. International Journal of Human Sciences, 11(2), 744-753. https://doi.org/10.14687/ijhs.v11i2.3018

Lirgg, C. D. (1991). Gender Differences in Self-Confidence in Physical Activity: A Meta-Analysis of Recent Studies. Journal of Sport and Exercise Psychology, 13(3), 294-310. https://doi.org/10.1123/jsep.13.3.294

Martens, R., Vealey, R. S., \& Burton, D. (1982). Competitive Anxiety in Sport. Human Kinetics.

McKay, M., \& Fanning, P. (2005). Self-Esteem. A Proven Program of Cognitive Techniques for Assesing, Improving and Maintaining Your Self-Esteem. New Harbinger Publications, Oakland, CA.

Miçooğulları, B. O., \& Kirazcı, S. (2010). Adaptation Study of Source of Sport Confidence Questionnaire for Turkish Population. Spor Bilimleri Dergisi, Hacettepe Üniversitesi, 21(4), 154-163.

Ryan, T. T., \& Pryor, F. D. (1976). Sex Cues in Estimating and Performing A Simple and Motor Task. Perceptual and Motor Skills, 43, 547-552. https://doi.org/10.2466/pms.1976.43.2.547

Tekin, H. (2002). Eğitimde Ölçme ve Değerlendirme. Yargı Yayıncılık, Ankara.

Vealey R. S. (1988). Sport-Confidence and Competitive Orientation: An Addendum on Scoring Procedures and Gender Differences. Journal of Sport \& Exercise Psychology, 10(4), 471-478. https://doi.org/10.1123/jsep.10.4.471

Vealey, R. S. (1986). Conceptualization of Sport-Confidence and Competitive Orientation: Preliminary Investigation and Instrument Development. Journal of Sport Psychology, 8(3) 221-246. https://doi.org/10.1123/jsp.8.3.221

Vealey, R. S. (2001). Understanding and Enhancing Self-Confidence in Athletes. In R. Singer, H. Hausenblaus, \& C. Janelle (Eds.), Handbook of sport psychology (2nd ed., pp. 550-563). New York: McMillan.

Vealey, R. S., Garner, H. M., Hayashi, S. W., \& Giacobbi, P. (1998). Sources of Sport-Confidence: Conceptualization and Instrument Development. Journal of Sport \& Exercise Psychology, 20(1), 54-80. https://doi.org/10.1123/jsep.20.1.54

Vurgun, N. (2010). Sporda imgeleme anketinin türkçeye uyarlanması ve sporda imgelemenin yarışma kaygısı ile sportif güven üzerindeki etkisi. Yayımlanmamış Doktora Tezi. Ege Üniversitesi. Sağlık Bilimleri Enstitüsü.

Weinberg, R. S., \& Gould, D. (2003). Foundations of Sport and Exercise Psychology (3rd) edition). Champaign, IL: Human Kinetics.

Yamak, B., Çebi, M., Eliöz, M., Küçük, H., \& Ceylan, L. (2007). Kadın Basketbolcuların Spor Yaşına Göre Sportif Güvenlerinin Karşılaştırılması. The International Balkan Conference In Sport Sciences, Book of Abstracts, 21-23 Mayls 2017. Bursa

Yıldırım, F. (2013). Sportif sürekli kendine güven alt ölçeğinin uyarlanması ve ortaöğretim kurumlarındaki öğrencilerde sportif sürekli kendine güvenin çeşitli değişkenler açısından incelenmesi. Yayımlanmamış Yüksek Lisans Tezi, Mersin Üniversitesi Ĕgitim Bilimleri Enstitüsü, Beden Ĕgitimi ve Spor Anabilim Dall, Mersin.

\section{Copyrights}

Copyright for this article is retained by the author(s), with first publication rights granted to the journal.

This is an open-access article distributed under the terms and conditions of the Creative Commons Attribution license which permits unrestricted use, distribution, and reproduction in any medium, provided the original work is properly cited. 